\title{
Antimicrobial and antioxidant activities of triterpenoid and phenolic derivatives from two Cameroonian Melastomataceae plants: Dissotis senegambiensis and Amphiblemma monticola
}

Raissa Tioyem Nzogong ${ }^{1 \dagger}$, Fabrice Sterling Tchantchou Ndjateu ${ }^{1,4 \dagger}$, Steve Endeguele Ekom², Jules-Arnaud Mboutchom Fosso ${ }^{2}$, Maurice Ducret Awouafack ${ }^{1,3}$, Mathieu Tene ${ }^{1 *}$, Pierre Tane ${ }^{1}$, Hiroyuki Morita ${ }^{3}$, Muhammad lqbal Choudhary ${ }^{4}$ and Jean-de-Dieu Tamokou ${ }^{2^{*}}$ (D)

\begin{abstract}
Background: Antimicrobial resistance is a serious threat against humankind and the search for new therapeutics is needed. This study aims to investigate the antimicrobial and antioxidant activities of ethanol extracts and compounds isolated from Dissotis senegambiensis and Amphiblemma monticola, two Cameroonian Melastomataceae species traditionally used for the treatment of fever, malaria and infectious diseases.

Methods: The plant extracts were prepared by maceration in ethanol. Standard chromatographic and spectroscopic methods were used to isolate and identify fourteen compounds from the two plant species [1-6 (from D. senegambiensis), 3, 4 and 7-14 (from A. monticola)]. A two-fold serial micro-dilution method was used to determine the minimum inhibitory concentration (MIC) against four bacterial strains including two resistant bacterial strains, methicillin resistant S. aureus (MRSA3) and methicillin resistant S. aureus (MRSA4) and three yeast strains.

Results: The fractionation of EtOH extracts afforded fourteen compounds belonging to triterpenoid and phenolic derivatives. The ethanol extracts, compounds 3,5-8, 10 and the mixture of $10+12$ were active against all the tested bacterial and fungal species. Compound $7(\mathrm{MIC}=16-32 \mu \mathrm{g} / \mathrm{mL})$ and $10(\mathrm{MIC}=8-16 \mu \mathrm{g} / \mathrm{mL})$ displayed the largest antibacterial and antifungal activities, respectively. Compounds 7, 10 and the mixture of $10+12$ showed prominent antibacterial activity against methicillin- resistant $S$. aureus (MRSA) which is in some cases equal to that of ciprofloxacin used as reference antibacterial drug. Compound 8 also showed high radical-scavenging activities and ferric reducing power when compared with vitamin C and butylated hydroxytoluene used as reference antioxidants. The tested samples were non-toxic to normal cells highlighting their good selectivity.
\end{abstract}

Conclusions: The result of this investigation reveals the potential of D. senegambiensis and A. monticola as well as the most active compounds in the search for new antimicrobial and antioxidant agents. So, further investigations are needed.

Keywords: Dissotis senegambiensis, Amphiblemma monticola, Melastomataceae, Triterpenoids, Phenolics, Antibacterial, Antifungal, Methicillin-resistant S. aureus

\footnotetext{
*Correspondence: mtene2001@yahoo.fr; jtamokou@yahoo.fr

${ }^{\dagger}$ Equal contributors

'Laboratory of Natural Products Chemistry, Department of Chemistry, Faculty

of Science, University of Dschang, P.O. Box 67, Dschang, Cameroon

${ }^{2}$ Laboratory of Microbiology and Antimicrobial substances, Department of

Biochemistry, Faculty of Science, University of Dschang, P.O. Box 67,

Dschang, Cameroon

Full list of author information is available at the end of the article
}

(c) The Author(s). 2018 Open Access This article is distributed under the terms of the Creative Commons Attribution 4.0 International License (http://creativecommons.org/licenses/by/4.0/), which permits unrestricted use, distribution, and reproduction in any medium, provided you give appropriate credit to the original author(s) and the source, provide a link to the Creative Commons license, and indicate if changes were made. The Creative Commons Public Domain Dedication waiver (http://creativecommons.org/publicdomain/zero/1.0/) applies to the data made available in this article, unless otherwise stated. 


\section{Background}

Infectious diseases are among the leading causes of death accounting for approximately one-half of all deaths in developing countries [1]. Despite the successes of the Millennium Development Goals era, the inhabitants of low-income countries still suffer an enormous burden of disease owing to diarrhoea, pneumonia, HIV/AIDS, tuberculosis, malaria and other infectious diseases. Increase in infections as a result of emergence of drug-resistant microorganisms and hitherto unknown pathogenic microbes pose enormous public health concerns [1]. These therefore, necessitate continued search for compounds with antimicrobial activities. Historically, plants have provided a good source of anti-infective agents in the fight against microbial infections [2-5]. The genus Dissotis which belongs to the Melastomataceae family comprises about 140 species in Africa [6]. They are climbing shrubs, shrubs or small trees found in some African countries such as Ivory Cost, Benin, Democratic Republic of Congo, Nigeria and Cameroon [7]. Several species are used in folk medicine as antidiarrheic, antimicrobial, antioxidant, antitumoral, antirheumatic, and anti-inflammatory agents, and also in the treatment of skin diseases, fever, malaria, and to lower blood cholesterol [8]. Dissotis senegambiensis (Guill. \& Perr.) Triana (Syn. Dissotis irvingiana Hook) belonging to the Melastomataceae family, is a shrub reaching $120 \mathrm{~cm}$ in height. The flowers are purple. In Africa, this plant species is found in tropical areas of Cameroon, Senegal, Ethiopia and Mozambique [7]. This species is used in traditional medicine for the treatment of the kwashiorkor, anemia, marasmus, avitaminose, drepanocytose, cutaneous eruptions and diarrhea [9]. To the best of our knowledge, no phytochemical work has yet been done on D. senegambiensis. The genus Amphiblemma belonging also to the Melastomataceae family, extends from tropical West Africa to Ethiopia and Cabinda. It contains at least 14 species distributed in Africa [10]. They are herbaceous plants or shrubs that grow in evergreen forests [10]. Amphiblemma monticola Jacq.-Fél. is a prostrate herb or sub-shrub reaching $100 \mathrm{~cm}$ in height that generally grows in West and SouthWest Regions of Cameroon [10-12]. This plant species is used by the Bamena populations in West Region of Cameroon against fever and stomach disorders [13]. Previous phytochemical studies of some species of the Melastomataceae family reported the isolation of terpenoids, steroids, simple phenolics, flavonoids and a vast range of polyphenols [14-18]. According to some traditional healers found in the Western region of Cameroon, maceration of the studied plants in raffia wine (a traditional alcoholic beverage produced in several African countries) is used for the treatment of different diseases. Traditional uses of $D$. senegambiensis and A. monticola motivated our effort to investigate the phytochemistry and pharmacological activity. Fourteen compounds $[\beta$-amyrin palmitate (1), $\alpha$-amyrin acetate (2), ursolic acid (3), sitosterol-3-O- $\beta$-D-glucopyranoside (4), vitexin (5) and trans-tiliroside (6) (from D. senegambiensis), ursolic acid (3), sitosterol3-O- $\beta$-D-glucopyranoside (4), 3,4'-di-O-methylellagic acid (7), dimethyl 4,4',5,5',6,6' -hexahydroxybiphenyl2,2'-dicarboxylate (8), lupeol (9), ellagic acid (10), 3hydroxy-4,5-dimethoxybenzoic acid (11), 3-O-methylellagic acid $4{ }^{\prime}-O-\beta$-D-xylopyranoside (12), oleanolic acid (13) and amphiblemmone A (14) (from A. monticola) ] were isolated and characterized. This is the first report on the isolation of compounds 1-6 from D. senegambiensis. Compounds 3, 4 and 7-14 were previously isolated from the same source (A. monticola) [13]. Antimicrobial and antioxidant activities of ethanol extracts of $D$. senegambiensis and A. monticola and some compounds (3-10, a mixture of 3 and 13, and a mixture of 10 and 12) isolated in sufficient quantities are reported here for the first time.

\section{Methods \\ General experimental procedures}

MS data were measured on JEOL MS Station JMS-700 spectrometer or JEOL 600 MS Route spectrometer. ${ }^{1} \mathrm{H}$ NMR (500 and $400 \mathrm{MHz}$ ) and ${ }^{13} \mathrm{C}$ NMR (125 and $100 \mathrm{MHz}$ ) were recorded using JEOL spectrometers or Bruker Avance AV-400 spectrometer. The chemical shifts were reported in parts per million (ppm) with TMS as internal standard. Deuterated solvents, methanol $\left(\mathrm{CD}_{3} \mathrm{OD}\right)$, dimethyl sulfoxide (DMSO- $\left.d_{6}\right)$, pyridine $\left(\mathrm{C}_{5} \mathrm{D}_{5} \mathrm{~N}\right)$ and chloroform $\left(\mathrm{CDCl}_{3}\right)$ were used as solvents for the NMR experiments. CC was performed on silica gel $60 \mathrm{~F}_{254}$ (70-230 mesh; Merck) and gel permeation on Sephadex LH-20. TLC was carried out on precoated silica gel Kieselgel $60 \mathrm{~F}_{254}$ plates $(0.25 \mathrm{~mm}$ thick), and spots weredetected with UV lights (254 and $365 \mathrm{~nm}$ ) and further sprayedwith $20 \% \mathrm{H}_{2} \mathrm{SO}_{4}$ reagent followed by heating to $100{ }^{\circ} \mathrm{C}$.

\section{Sample collections}

Plant materials were collected in two locations of the Western Region of Cameroon: the whole plant of Dissotis senegambiensis (Guill. \& Perr.) Triana in Bansoa (January 2013) and the roots of Amphiblemma monticola Jacq.-Fél. in Bamena (May 2016). Their identification was done by Mr. Fulbert Tadjouteu, a botanist of the Cameroon National Herbarium in Yaoundé, where voucher specimens, $\mathrm{N}^{\mathrm{o}}$ 24736/SRF/Cam (D. senegambiensis) and $\mathrm{N}^{\mathrm{O}} 45094 /$ HNC (A. monticola), were deposited.

\section{Extraction}

The powdered material of D. senegambiensis $(1.8 \mathrm{~kg})$ was extracted three times ( $72 \mathrm{~h}$ for each time) by maceration with ethanol $(8 \mathrm{~L})$ at room temperature. Evaporation of solvent under vacuum afforded $78 \mathrm{~g}$ of crude extract. A 
portion of this extract (76 g) was successively triturated with $n$-hexane, EtOAc and $n$-butanol. TLC analysis showed that the $n$-hexane and EtOAc extracts (19.5 and $20.5 \mathrm{~g}$, respectively) were qualitatively the same. They were thus combined to afford $40 \mathrm{~g}$ of extract called "EtOAc extract".

Dried and pulverized roots $(1.5 \mathrm{~kg})$ and aerial part $(0.08 \mathrm{~kg})$ of $A$. monticola were respectively macerated with ethanol ( $5 \mathrm{~L}$ with roots and $1 \mathrm{~L}$ with aerial part) for $24 \mathrm{~h}$ (3 times) at room temperature. Evaporation of solvent under reduced pressure afforded $49 \mathrm{~g}$ and $4.28 \mathrm{~g}$ of crude extracts, respectively.

\section{Phytochemical analysis}

The extracts were screened for secondary metabolites using standard procedures as previously described [19-22]. The plant extracts were screened for the presence of different classes of compounds including triterpenoids, steroids, flavonoids, phenols, glycosides, tannins and alkaloids.

\section{Isolation of constituents}

A portion (38 g) of "EtOAc extract" of D. senegambiensis was subjected to silica gel (70 to 230 mesh) column chromatography $(\mathrm{CC})$ eluted with gradient of $n$-hexaneEtOAc (100:0, 9:1, 4:1, 7:3, 3:2, 1:1 and 0:100) followed by gradient of EtOAc-MeOH (19:1, 9:1, 4:1, 7:3, 1:1 and $0: 100$ ). Fifty-five fractions of $300 \mathrm{~mL}$ each were collected and combined into six major fractions on the basis of their TLC profiles: A $(1-6 ; 4.0 \mathrm{~g}), \mathrm{B}(7-12 ; 4.5 \mathrm{~g}), \mathrm{C}$ (13-17; $3.6 \mathrm{~g}), \mathrm{D}(18-26 ; 4.7 \mathrm{~g}), \mathrm{E}(27-36 ; 5.5 \mathrm{~g})$, and F $(37-55 ; 9.1 \mathrm{~g})$. Fraction A crystallized to afford a mixture of two compounds. This mixture was subjected to silica gel CC and eluted with $n$-hexane- EtOAc (49:1) to yield $\beta$-amyrin palmitate $(4.2 \mathrm{mg} ; \mathbf{1})$ and $\alpha$-amyrin acetate $(3$. $5 \mathrm{mg} ; 2)$. Fraction $\mathrm{C}$ crystallized to afford ursolic acid (15.0 mg; 3). Fraction $\mathrm{E}$ was subjected to silica gel CC and eluted with $\mathrm{CH}_{2} \mathrm{Cl}_{2}-\mathrm{MeOH}$ mixture of increasing polarity to yield sitosterol-3-O- $\beta$-D-glucopyranoside (35. $1 \mathrm{mg} ; 4)$ and vitexin (28.5 mg; 5). Similarly as with fraction $\mathrm{E}$, fraction $\mathrm{F}$ afforded trans-tiliroside $(25.0 \mathrm{mg}$; 6). A portion $(18 \mathrm{~g})$ of the $n-\mathrm{BuOH}$ extract was also subjected to silica gel $\mathrm{CC}$ eluted with gradient of $\mathrm{CH}_{2} \mathrm{Cl}_{2}-\mathrm{MeOH}$ (100:0, 19:1, 9:1, 4:1and 0:100). Twentytwo fractions of $300 \mathrm{~mL}$ each were collected and combined into four major fractions on the basis of their TLC profiles: G (1-7; $2.7 \mathrm{~g}), \mathrm{H}$ (8-12; $3.5 \mathrm{~g})$, I (13-18; $3.6 \mathrm{~g})$ and $\mathrm{J}(19-22 ; 3.7 \mathrm{~g})$. Fraction $\mathrm{G}$ was subjected to silica gel $\mathrm{CC}$ and eluted with $\mathrm{CH}_{2} \mathrm{Cl}_{2}-\mathrm{MeOH}$ mixture of increasing polarity to yield vitexin (15.1 $\mathrm{mg} ; 5)$ and trans-tiliroside ( $13.1 \mathrm{mg} ; \mathbf{6})$. An attempt to purify fractions $\mathrm{B}, \mathrm{D}, \mathrm{H}, \mathrm{I}$ and $\mathrm{J}$ failed.

A portion $(47 \mathrm{~g})$ of EtOH extract of the roots of $A$. monticola was fractionated on silica gel $\mathrm{CC}$ eluted with $\mathrm{CH}_{2} \mathrm{Cl}_{2}-\mathrm{MeOH}$ of increasing polarity to give 25 fractions of $300 \mathrm{~mL}$ each. After comparative TLC, they were combined into 4 major fractions: A $(1-8 ; 7.6 \mathrm{~g}), \mathrm{B}(9-16$; $11 \mathrm{~g}), \mathrm{C}(17-21 ; 5.1 \mathrm{~g})$ and D $(22-25 ; 5.8 \mathrm{~g})$. Fraction A was chromatographed on a silica gel column eluted with a continuous gradient of $n$-hexane-EtOAc to afford lupeol $(9,120.8 \mathrm{mg})$ and a mixture of sterols. Similarly, fractions B and $\mathrm{C}$ were eluted with $\mathrm{CH}_{2} \mathrm{Cl}_{2}-\mathrm{MeOH}$ of increasing polarity yielding four (B1-B4) and three (C1-C3) sub-fractions, respectively. B2 (1.9 g), B3 (2.3 g), C2 $(1.9 \mathrm{~g})$ and $\mathrm{C} 3(1.2 \mathrm{~g})$ were passed separately on LH-20 Sephadex $\mathrm{CC}$ eluted with $\mathrm{CH}_{2} \mathrm{Cl}_{2}-\mathrm{MeOH}$ (1:1) to give 3,4'-di-O-methylellagic acid (20.0 mg; 7) from B2, dimethyl $4,4^{\prime}, 5,5^{\prime}, 6,6^{\prime}$-hexahydroxybiphenyl-2,2' -dicarboxylate (15.0 mg; 8) from B3, ellagic acid (23.0 mg; 10), 3-hydroxy-4,5-dimethoxybenzoic acid (4.0 mg; 11) and a mixture of $\mathbf{1 0}$ and $\mathbf{1 2}(7.0 \mathrm{mg})$ from $\mathrm{C} 2$, and 3-O-methylellagic acid 4'-O- $\beta$-D-xylopyranoside $(2.3 \mathrm{mg} ; 12)$ from C3. Re-crystallization of B4 (0.7 g) in EtOAc afforded a mixture (31.9 mg) of ursolic acid (3) and oleanolic acid (13). Fraction D was subjected to silica gel CC eluted with a gradient mixture of $\mathrm{CH}_{2} \mathrm{Cl}_{2}-\mathrm{MeOH}$ to afford four sub-fractions (D1-D4). Repeated silica gel CC of D2 (0.8 g), eluted with $\mathrm{CH}_{2} \mathrm{Cl}_{2}-\mathrm{MeOH}$ (from 49:1 to 9:1) gave sitosterol-3-O- $\beta$-D-glucopyranoside $(45.0 \mathrm{mg} ; 4)$ and amphiblemmone A (9.7 mg; 14).

Due to the small quantity of plant material, the aerial part of A. monticola (4.28 g of crude EtOH extract), compared to the roots (same collection in the field), was not further studied in this work.

\section{Antimicrobial activity of extracts and compounds Tested microorganisms}

The microorganisms used in this study include four bacterial (Staphylococcus aureus ATCC25923, methicillin sensitive $S$. aureus MSSA1, methicillin resistant $S$. aureus MRSA3 and methicillin resistant $S$. aureus MRSA4) and three yeast strains (Candida albicans ATCC10231, Candida tropicalis PK233 and Cryptococcus neoformans H99). These microorganisms were taken from our laboratory collection. The fungal and bacterial strains were grown at $37^{\circ} \mathrm{C}$ and maintained on Sabouraud Dextrose Agar (SDA, Conda, Madrid, Spain) and nutrient agar (NA, Conda) slants respectively.

\section{Inocula preparation}

The inocula of bacteria and yeasts were prepared from overnight cultures as previously described [23]. Absorbance was read spectrophotometrically at $530 \mathrm{~nm}$ and $600 \mathrm{~nm}$ for yeasts and bacteria respectively. The final concentrations of microbial suspensions were $2.5 \times 10^{5}$ cells $/ \mathrm{mL}$ for yeasts and $10^{6} \mathrm{CFU} / \mathrm{mL}$ for bacteria.

\section{Antimicrobial assay}

The antimicrobial activity was evaluated by determining the minimum inhibitory concentrations (MICs). MICs of 
extracts and compounds were determined by broth micro dilution [24]. Each test sample was dissolved in $10 \% \mathrm{v} / \mathrm{v}$ aqueous dimethylsulfoxide (DMSO) to give a stock solution. This was serially diluted two-fold in Mueller-Hinton Broth (MHB) for bacteria and Sabouraud Dextrose Broth (SDB) for fungi to obtain a concentration range of 4096 to $0.25 \mu \mathrm{g} / \mathrm{mL}$. Then, $100 \mu \mathrm{L}$ of each sample concentration was added to respective wells (96-well micro plate) containing $90 \mu \mathrm{L}$ of SDB/ MHB and $10 \mu \mathrm{L}$ of inoculum to give final concentration ranges of 2048 to $4 \mu \mathrm{g} / \mathrm{mL}$ (for extracts) and 256 to $0.125 \mu \mathrm{g} / \mathrm{mL}$ (for compounds). Dilutions of nystatin (Sigma-Aldrich, Steinheim, Germany) and ciprofloxacin (Sigma-Aldrich, Steinheim, Germany) were used as positive controls for yeasts and bacteria respectively. Broth with $10 \mu \mathrm{L}$ of DMSO was used as negative control. The cultured micro plates were covered; then, the contents of each well were mixed thoroughly using a plate shaker (Flow Laboratory, Germany) and incubated at $37{ }^{\circ} \mathrm{C}$ for $24 \mathrm{~h}$ (bacteria) and $48 \mathrm{~h}$ (yeasts) under shaking. After the incubation period, MICs were assessed visually and were taken as the lowest sample concentration at which there was no growth or virtually no growth. The lowest concentration that yielded no growth after the subculturing was considered as the minimum microbicidal concentrations (MMCs). All the tests were performed in triplicate.

\section{Antioxidant assay}

\section{Ferric reducing antioxidant power (FRAP) assay}

The FRAP was determined by the $\mathrm{Fe}^{3+}-\mathrm{Fe}^{2+}$ transformation in the presence of extracts and compounds as previously described [25]. The $\mathrm{Fe}^{2+}$ was monitored by measuring the formation of Perl's Prussian blue at $700 \mathrm{~nm}$. Butylated hydroxytoluene (BHT) was used as a positive control. All the tests were performed in triplicate.

\section{Diphenyl-1-picrylhydrazyl (DPPH) free radical scavenging assay}

The free radical scavenging activity of extracts and compounds was evaluated according to described methods [26]. The $\mathrm{EC}_{50}(\mu \mathrm{g} / \mathrm{ml})$, which is the amount of sample necessary to inhibit by $50 \%$ the absorbance of free radical DPPH was calculated [26]. Vitamin $C$ was used as a standard control. All the analyses were carried out in triplicate.

\section{Hemolytic assay}

Whole blood $(10 \mathrm{~mL})$ from albino rats was collected by cardiac puncture into a conical tube containing EDTA as an anticoagulant. The study was conducted according to the ethical guidelines of the Committee for Control and Supervision of Experiments on Animals (Registration no. 173/CPCSEA, dated 28 January,
2000), Government of India, on the use of animals for scientific research. Erythrocytes were harvested by centrifugation at room temperature for $10 \mathrm{~min}$ at $1000 \times \mathrm{g}$ and were washed three times in PBS buffer [27]. The cytotoxicity was evaluated as previously described [27].

\section{Statistical analysis}

Data were analyzed by one-way analysis of variance followed by Waller-Duncan Post Hoc test. The experimental results were expressed as the mean \pm Standard Deviation (SD). Differences between groups were considered significant when $p<0.05$. All analyses were performed using the Statistical Package for Social Sciences (SPSS, version 12.0) software.

\section{Results}

\section{Chemical analysis}

The phytochemical screening revealed the presence of steroids, phenols, glycosides and tannins in all the plant extracts (Table 1). Triterpenoids and flavonoids are selectively distributed in the extracts whereas alkaloids were absent in all the extracts (Table 1). The EtOAc and $n$ - $\mathrm{BuOH}$ extracts from $D$. senegambiensis and $\mathrm{EtOH}$ extract from the roots of $A$. monticola were fractionated by silica gel column chromatography to afford fourteen compounds (1-14) (Fig. 1). Compounds obtained from $D$. senegambiensis were identified as $\beta$-amyrin palmitate (1) [28], $\alpha$-amyrin acetate (2) [29], ursolic acid (3) [30], sitosterol-3-O- $\beta$-D-glucopyranoside (4) [31]; vitexin (5) [32] and trans-tiliroside (6) [33]. From A. monticola, compounds were identified as 3,4'-di- $O$-methylellagic acid (7) [34], dimethyl 4,4',5,5',6,6'-hexahydroxybiphenyl-2,2' -dicarboxylate (8) [35], lupeol (9) [36], ellagic acid (10) [16], 3-hydroxy-4,5-dimethoxybenzoic acid (11) [37], 3-O-methylellagic acid 4'-O- $\beta$-D-xylopyranoside (12) [38], oleanolic acid (13) [16], and amphiblemmone A (14) [13]. The structures of the compounds

Table 1 Secondary metabolites identified in the studied plant extracts

\begin{tabular}{|c|c|c|c|c|c|}
\hline \multirow[t]{3}{*}{ Metabolites } & \multirow{2}{*}{\multicolumn{3}{|c|}{$\begin{array}{l}\text { D. senegambiensis } \\
\text { Whole plant }\end{array}$}} & \multicolumn{2}{|c|}{ A. monticola } \\
\hline & & & & \multirow{2}{*}{$\begin{array}{l}\text { Roots } \\
\text { Crude } \\
\text { EtOH } \\
\text { extract }\end{array}$} & \multirow{2}{*}{$\begin{array}{l}\text { Aerial part } \\
\text { Crude } \\
\text { EtOH } \\
\text { extract }\end{array}$} \\
\hline & $\begin{array}{l}\text { Crude } \\
\text { EtOH } \\
\text { extract }\end{array}$ & $\begin{array}{l}\text { EtOAc } \\
\text { extract }\end{array}$ & $\begin{array}{l}n-\mathrm{BuOH} \\
\text { extract }\end{array}$ & & \\
\hline Triterpenoids & + & + & - & + & + \\
\hline Steroids & + & + & + & + & + \\
\hline Flavonoids & + & + & + & + & - \\
\hline phenols & + & + & + & + & + \\
\hline Tannins & + & + & + & + & + \\
\hline Glycosides & + & + & + & + & + \\
\hline Alkaloids & - & - & - & - & - \\
\hline
\end{tabular}

(+): presence; $(-)$ : absence 


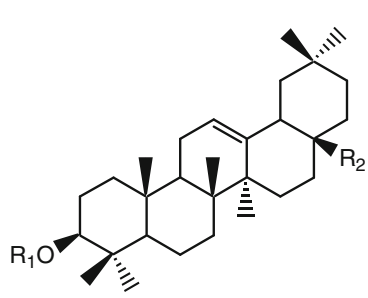

$1: \mathrm{R}_{1}=$ Palmitoyl $\mathrm{R}_{2}=\mathrm{Me}$

$13: \mathrm{R}_{1}=\mathrm{H} ; \mathrm{R}_{2}=\mathrm{COOH}$

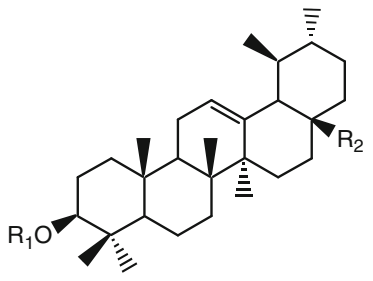

$2: \mathrm{R}_{1}=$ Acetyl $; \mathrm{R}_{2}=\mathrm{Me}$

$3: \mathrm{R}_{1}=\mathrm{H} ; \mathrm{R}_{2}=\mathrm{COOH}$<smiles></smiles><smiles></smiles><smiles>CCCOc1c(O)cc2c(=O)oc3c(O)c(O)cc4c(=O)oc1c2c34</smiles>

$7 \mathrm{R}_{1}=\mathrm{R}_{2}=\mathrm{Me}$

$10 R_{1}=R_{2}=H$<smiles>COC(=O)c1cc(O)c(O)c(O)c1-c1c(C(=O)OC)cc(O)c(O)c1O</smiles>

$12 R_{1}=$ Me: $R_{2}=x y l$

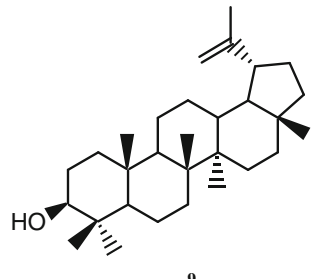<smiles>COc1cc(C(=O)O)cc(O)c1OC</smiles>

11<smiles>COc1ccc(-c2coc3c([N+](=O)[O-])c(O)c(C)c(O)c3c2=O)cc1</smiles>

14

Fig. 1 Chemical structures of compounds isolated from $D$. senegambiensis (1-6) and A. monticola (3, 4, 7-14). 1: $\beta$-amyrin palmitate; 2 : $a$-amyrin acetate; 3: ursolic acid; 4: sitosterol 3-O- $\beta$-D-glucopyranoside; $\mathbf{5}$ : vitexin; $\mathbf{6}$ : trans-tilliroside; 7: 3,4'-di-O-methylellagic acid; 8: dimethyl 4,4',5,5',6,6'hexahydroxybiphenyl-2,2'-dicarboxylate; 9: lupeol; 10: ellagic acid; 11: 3-hydroxy-4,5-dimethoxybenzoic acid; 12: 3-O-methylellagic acid 4'-O- $\beta$-Dxylopyranoside; 13: oleanolic acid; 14: amphiblemmone A

(Fig. 1) were determined by analysis of their NMR data and comparison with those reported in the literature (Additional file 1).

\section{Antimicrobial activity}

The antimicrobial activity of EtOH extracts from $D$. senegambiensis and A. monticola as well as their isolated compounds was performed against four bacterial strains including two resistant bacterial strains, methicillin resistant S. aureus (MRSA3) and methicillin resistant $S$. aureus (MRSA4) and three yeast strains (Table 2). The EtOH, EtOAc and $n-\mathrm{BuOH}$ extracts, as well as compounds 3, 5$8, \mathbf{1 0}$ and the mixture of $\mathbf{1 0}+\mathbf{1 2}$ were active against all the tested bacterial and fungal species. Among the extracts, the EtOH extract from D. senegambiensis (MIC $=64-256 \mu \mathrm{g} /$ $\mathrm{mL}$ ) was the most active against $S$. aureus strains whereas 
Table 2 Antimicrobial activity (in $\mu \mathrm{g} / \mathrm{ml}$ ) of extracts and isolated compounds from D. senegambiensis and A. monticola against bacterial and yeast strains

\begin{tabular}{|c|c|c|c|c|c|c|c|c|}
\hline $\begin{array}{l}\text { Crude extracts/ } \\
\text { compounds }\end{array}$ & $\begin{array}{l}\text { Inhibition } \\
\text { parameters }\end{array}$ & $\begin{array}{l}\text { S. aureus } \\
\text { ATCC25923 }\end{array}$ & S. aureus MSSA1 & S. aureus MRSA3 & S. aureus MRSA4 & $\begin{array}{l}\text { C. albicans } \\
\text { ATCC10231 }\end{array}$ & $\begin{array}{l}\text { C. tropicalis } \\
\text { PK233 }\end{array}$ & C. neoformans $\mathrm{H} 99$ \\
\hline \multirow[t]{3}{*}{ DSEtOH } & MIC & 128 & 64 & 256 & 128 & 2048 & 1024 & 512 \\
\hline & MMC & 256 & 128 & 512 & 256 & 2048 & 2048 & 1024 \\
\hline & MMC/MIC & 2 & 2 & 2 & 2 & 1 & 2 & 2 \\
\hline \multirow[t]{3}{*}{ DSEtOAC } & MIC & 256 & 128 & 256 & 256 & 2048 & 1024 & 512 \\
\hline & MMC & 256 & 256 & 512 & 512 & $>2048$ & $>2048$ & $>2048$ \\
\hline & MMC/MIC & 1 & 2 & 2 & 1 & nd & nd & nd \\
\hline \multirow[t]{3}{*}{ DSBuOH } & MIC & 256 & 64 & 256 & 128 & 2048 & 1024 & 1024 \\
\hline & MMC & 512 & 128 & 512 & 256 & 2048 & $>2048$ & $>2048$ \\
\hline & MMC/MIC & 2 & 2 & 2 & 2 & 1 & nd & nd \\
\hline \multirow[t]{3}{*}{ AMEtOH } & MIC & 256 & 128 & 256 & 256 & 256 & 128 & 256 \\
\hline & MMC & 256 & 128 & 512 & 512 & 512 & 256 & 256 \\
\hline & MMC/MIC & 1 & 1 & 2 & 2 & 2 & 2 & 1 \\
\hline \multirow[t]{3}{*}{ AMEtOAc } & MIC & 512 & 256 & 512 & 512 & 512 & 2048 & 2048 \\
\hline & MMC & 512 & 512 & 512 & 512 & 1024 & $>2048$ & $>2048$ \\
\hline & MMC/MIC & 1 & 2 & 1 & 1 & 2 & nd & nd \\
\hline \multirow[t]{3}{*}{3} & MIC & 256 & 128 & 128 & 128 & 256 & 256 & 128 \\
\hline & MMC & $>256$ & $>256$ & $>256$ & $>256$ & $>256$ & $>256$ & $>256$ \\
\hline & MMC/MIC & nd & nd & $\mathrm{Nd}$ & nd & nd & nd & nd \\
\hline \multirow[t]{3}{*}{4} & MIC & $>256$ & $>256$ & $>256$ & $>256$ & 256 & 256 & 128 \\
\hline & MMC & $>256$ & $>256$ & $>256$ & $>256$ & $>256$ & $>256$ & $>256$ \\
\hline & MMC/MIC & nd & nd & $\mathrm{Nd}$ & nd & nd & nd & nd \\
\hline \multirow[t]{3}{*}{5} & MIC & 64 & 64 & 64 & 128 & 128 & 64 & 128 \\
\hline & MMC & 128 & 128 & 128 & 256 & 256 & 128 & 128 \\
\hline & MMC/MIC & 2 & 2 & 2 & 2 & 2 & 2 & 1 \\
\hline \multirow[t]{3}{*}{6} & MIC & 32 & 64 & 64 & 128 & 64 & 64 & 64 \\
\hline & MMC & 64 & 64 & 128 & 128 & 64 & 64 & 128 \\
\hline & MMC/MIC & 2 & 1 & 2 & 1 & 1 & 1 & 2 \\
\hline \multirow[t]{3}{*}{7} & MIC & 32 & 16 & 16 & 32 & 32 & 32 & 32 \\
\hline & MMC & 32 & 16 & 32 & 64 & 64 & 64 & 32 \\
\hline & MMC/MIC & 1 & 1 & 2 & 2 & 2 & 2 & 1 \\
\hline \multirow[t]{3}{*}{8} & MIC & 32 & 32 & 64 & 128 & 128 & 16 & 32 \\
\hline & MMC & 64 & 32 & 128 & 256 & $>256$ & 16 & 32 \\
\hline & MMC/MIC & 2 & 1 & 2 & 2 & nd & 1 & 1 \\
\hline \multirow[t]{3}{*}{9} & MIC & 256 & 256 & $>256$ & $>256$ & $>256$ & 256 & 256 \\
\hline & MMC & $>256$ & $>256$ & $>256$ & $>256$ & nd & $>256$ & $>256$ \\
\hline & MMC/MIC & nd & nd & $\mathrm{Nd}$ & nd & nd & nd & nd \\
\hline \multirow[t]{3}{*}{10} & MIC & 8 & 16 & 32 & 32 & 16 & 8 & 16 \\
\hline & MMC & 16 & 16 & 64 & 32 & 16 & 8 & 16 \\
\hline & MMC/MIC & 2 & 1 & 2 & 1 & 1 & 1 & 1 \\
\hline \multirow[t]{3}{*}{$10+12$} & MIC & 32 & 16 & 32 & 32 & 64 & 64 & 64 \\
\hline & MMC & 64 & 64 & 64 & 64 & 128 & 128 & 64 \\
\hline & MMC/MIC & 2 & 4 & 2 & 2 & 2 & 2 & 1 \\
\hline $3+13$ & MIC & 128 & 64 & $>256$ & 128 & $>256$ & $>256$ & 128 \\
\hline
\end{tabular}


Table 2 Antimicrobial activity (in $\mu \mathrm{g} / \mathrm{ml}$ ) of extracts and isolated compounds from D. senegambiensis and A. monticola against bacterial and yeast strains (Continued)

\begin{tabular}{|c|c|c|c|c|c|c|c|c|}
\hline $\begin{array}{l}\text { Crude extracts/ } \\
\text { compounds }\end{array}$ & $\begin{array}{l}\text { Inhibition } \\
\text { parameters }\end{array}$ & $\begin{array}{l}\text { S. aureus } \\
\text { ATCC25923 }\end{array}$ & S. aureus MSSA1 & S. aureus MRSA3 & S. aureus MRSA4 & $\begin{array}{l}\text { C. albicans } \\
\text { ATCC10231 }\end{array}$ & $\begin{array}{l}\text { C. tropicalis } \\
\text { PK233 }\end{array}$ & C. neoformans H99 \\
\hline & MMC & 256 & 128 & $\mathrm{Nd}$ & 256 & $>256$ & $>256$ & 256 \\
\hline & MMC/MIC & 2 & 2 & nd & 2 & nd & nd & 2 \\
\hline \multirow[t]{3}{*}{ Reference drugs* } & MIC & 1 & 1 & 16 & 32 & 2 & 0.5 & 1 \\
\hline & MMC & 1 & 1 & 16 & 32 & 2 & 1 & 1 \\
\hline & MMC/MIC & 1 & 1 & 1 & 1 & 1 & 2 & 1 \\
\hline
\end{tabular}

*: Ciprofloxacin for bacteria and nystatin for fungi; compounds 1-6 and compounds 3, 4, 7-14 were isolated from D. senegambiensis and A. monticola respectively; compounds 1-2, 11 and 14 were not tested; nd: not determined. MIC: Minimum Inhibitory Concentrations; MMC: Minimum Microbicidal Concentrations; $\mathrm{DSEtOH}=D$. senegambiensis $\mathrm{EtOH}$ extract; $\mathrm{DSEtOAc}=D$. senegambiensis EtOAc extract; $\mathrm{DSBuOH}=D$. senegambiensis $n$-BuOH extract; $\mathrm{AMEtOH}=A$. monticola EtOH extract; AMEtOAC = A. monticola EtOAc extract; 3: ursolic acid; 4: sitosterol 3-O- $\beta$-D-glucopyranoside; 5: vitexin; 6: trans-tilliroside; 7: 3,4'-di-Omethylellagic acid; 8: dimethyl 4,4',5,5',6,6'-hexahydroxybiphenyl-2,2'-dicarboxylate; 9: lupeol; 10: ellagic acid; 12: 3-O-methylellagic acid 4'-O- $\beta$-D-xylopyranoside; 13: oleanolic acid

the A. monticola EtOH extract $(\mathrm{MIC}=128-256 \mu \mathrm{g} / \mathrm{mL})$ was the most effective against yeast strains. The results also showed that S. aureus ATCC25923 and S. aureus MSSA1 were the most sensitive bacteria while the most sensitive fungi were C. tropicalis and C. neoformans. Compound $\mathbf{1 0}$ ( $\mathrm{MIC}=8-16 \mu \mathrm{g} / \mathrm{mL}$ ) displayed the largest antifungal activity whereas compound $7(\mathrm{MIC}=16-32 \mu \mathrm{g} / \mathrm{ml})$ showed the best anti-staphylococcal activity. Compound 10 (MIC $=8-32 \mu \mathrm{g} / \mathrm{mL}$ ) was the most active sample against bacterial and fungal strains following in decreasing order by 7 $(\mathrm{MIC}=16-32 \mu \mathrm{g} / \mathrm{mL}), \mathbf{1 0}+12(\mathrm{MIC}=16-64 \mu \mathrm{g} / \mathrm{mL}), 8$ $(\mathrm{MIC}=8-128 \mu \mathrm{g} / \mathrm{mL}), 6(\mathrm{MIC}=32-128 \mu \mathrm{g} / \mathrm{mL}), 5(\mathrm{MIC}$ $=64-128 \mu \mathrm{g} / \mathrm{mL}), \quad 3 \quad(\mathrm{MIC}=128-256 \mu \mathrm{g} / \mathrm{mL}), \quad 3+13$ $(\mathrm{MIC}=64->256 \mu \mathrm{g} / \mathrm{mL}), 9(\mathrm{MIC}=256->256 \mu \mathrm{g} / \mathrm{mL})$ and $4(\mathrm{MIC}=128->256 \mu \mathrm{g} / \mathrm{mL})$. Compounds $\mathbf{1}$ and 2, obtained in small quantities, were not tested against the microorganisms used. The standard drugs used in this study were ciprofloxacin and nystatin for antibacterial and antifungal activity, respectively, and the antibacterial activities of some of the isolated compounds are in some cases equal to those of ciprofloxacin whereas the antifungal activity of the isolated compounds is lesser than that of nystatin.

\section{Ferric reducing antioxidant power (FRAP)}

In this study, all the investigated samples showed concentration-dependent reducing power (Fig. 2). The EtOH extracts from $D$. senegambiensis and A. monticola displayed the largest reductive abilities when compared with their fractions. Interestingly, compounds 7 and $\mathbf{1 0 +}$ 12 showed the lowest reducing power whereas compound 8 exhibited the highest reducing power at the different concentrations tested. The antioxidant power of compound $\mathbf{8}$ is almost equal to that of butylated hydroxytoluene (BHT) used as standard antioxidant.

\section{DPPH free radical scavenging activity}

The results of the radical-scavenging activity showed that compounds 7 and $\mathbf{1 0}+\mathbf{1 2}$ had the highest $\mathrm{EC}_{50}$ (i.e. the lowest activity) while compound $\mathbf{8}$ had the lowest $\mathrm{EC}_{50}$ (i.e. the highest activity) (Fig. 3). Among the extracts, $A$. monticola EtOAc extract $\left(\mathrm{EC}_{50}=40.83 \pm 1.57 \mu \mathrm{g} / \mathrm{ml}\right)$ displayed the lowest activity whereas $D$. senegambiensis and $A$. monticola $\mathrm{EtOH}$ extracts had the highest activity $\left(\mathrm{EC}_{50}=22\right.$. $48 \pm 1.62$ and $19.74 \pm 1.98 \mu \mathrm{g} / \mathrm{ml})$. The DPPH free radical scavenging activity of compound $\mathbf{8}$ was comparable to that of the standard antioxidant vitamin $\mathrm{C}$. These results corroborate the FRAP assay, where this compound exhibited the best antioxidant activity.

\section{Hemolytic activity}

To investigate the potential use of extracts and compounds 1-14, the cytotoxicity also has to be evaluated. In this study, none of the tested samples showed hemolytic activities against red blood cells at concentrations up to $256 \mu \mathrm{g} / \mathrm{mL}$ and $2048 \mu \mathrm{g} / \mathrm{mL}$ for isolated compounds and extracts respectively (results not shown). This finding highlights the fact that the observed biological activity is not due to cellular toxicity.

\section{Discussion}

The findings of the present study showed that there were differences between the antimicrobial activities of plant extracts. These differences may be due to the different groups of secondary metabolites found in these extracts. Indeed, the antimicrobial activity of medicinal plants is correlated with the presence in their extracts of one or more classes of bioactive secondary metabolites [39]. The results also showed that the fractionation of EtOH extracts of $D$. senegambiensis and A. monticola reduced their antimicrobial activity in EtOAc and $n-\mathrm{BuOH}$ extracts. This indicates that the active principles might be more concentrated in the EtOH extracts and more diluted in their fractions. The antimicrobial activity of plant extracts is considered to be highly active if the $\mathrm{MIC}<100 \mu \mathrm{g} / \mathrm{mL} ;$ significantly active when $100 \leq \mathrm{MIC}$ $\leq 512 \mu \mathrm{g} / \mathrm{mL} ;$ moderately active when $512<\mathrm{MIC}$ 


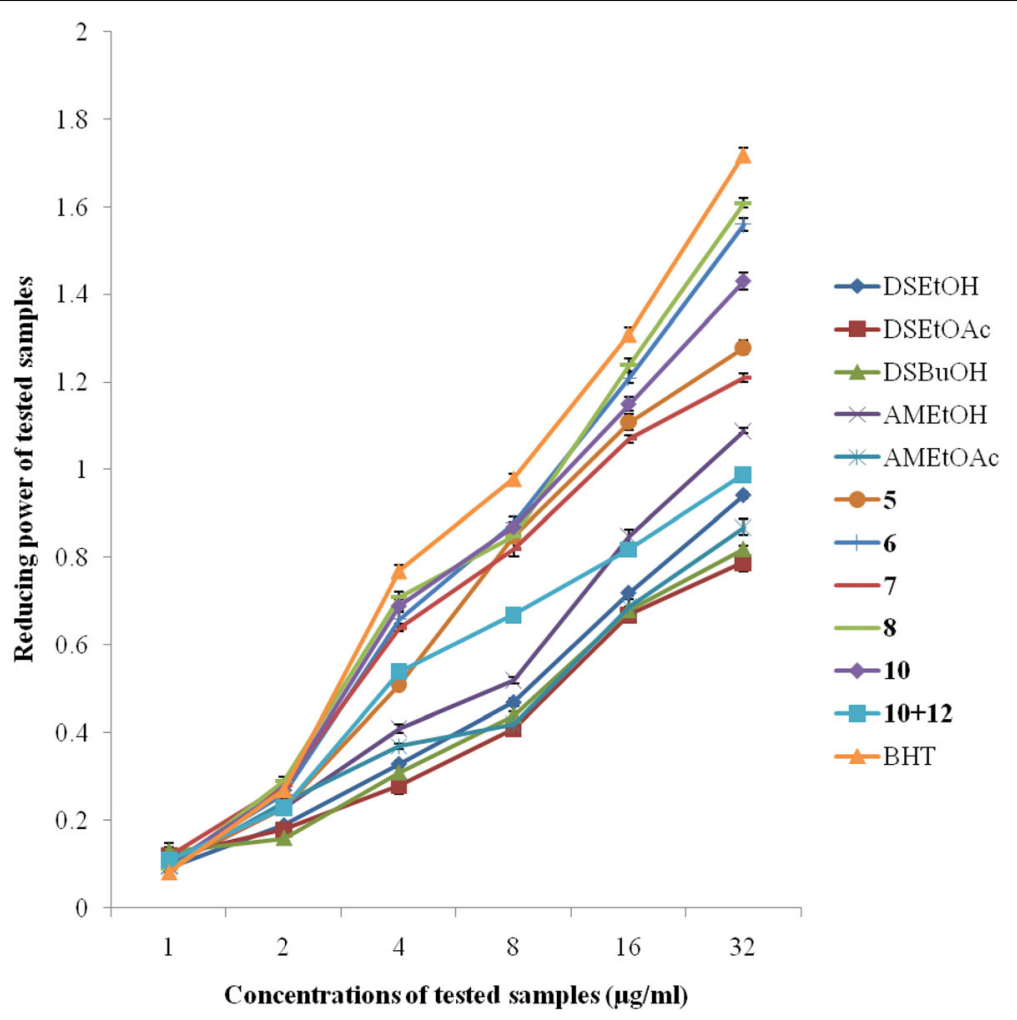

Fig. 2 Reducing power activities of the tested samples as well as butylated hydroxytoluene (BHT). Results represent the mean \pm standard deviation of the triplicate reducing power at each concentration. Compounds $\mathbf{1 - 2}, \mathbf{1 1}$ and $\mathbf{1 4}$ were not tested; compounds $\mathbf{3 - 4}, \mathbf{9}$ and $\mathbf{1 3}$ were not active; $\mathrm{DSEtOH}=D$. senegambiensis EtOH extract; $\mathrm{DSEtOAc}=D$. senegambiensis EtOAc extract; $\mathrm{DSBuOH}=\mathrm{D}$. senegambiensis $n$-BuOH extract; $\mathrm{AMEtOH}=$ A. monticola EtOH extract; $\mathrm{AMEtOAc}=$ A. monticola EtOAc extract

$\leq 2048 \mu \mathrm{g} / \mathrm{mL}$; weakly active if $\mathrm{MIC}>2048 \mu \mathrm{g} / \mathrm{mL}$ and not active when MIC $>10 \mathrm{mg} / \mathrm{mL}[40]$. Hence, the $\mathrm{EtOH}$ extract of $D$. senegambiensis was highly active $(\mathrm{MIC}<100 \mu \mathrm{g} / \mathrm{mL})$ against S. aureus MSSA1; significantly active $(100 \leq \mathrm{MIC} \leq 512 \mu \mathrm{g} / \mathrm{mL})$ against $S$. aureus ATCC25923, S. aureus MRSA3, S. aureus MRSA4 and C. neoformans; moderately active $(512<$ MIC $\leq 2048 \mu \mathrm{g} /$ $\mathrm{mL}$ ) on C. albicans and C. tropicalis. The antibacterial and antifungal activities of extracts support the use of $D$. senegambiensis and A. monticola in traditional medicine for the treatment of microbial infections.

Antimicrobial cutoff points have been defined in the literature to enable the understanding of the potential of pure compounds as follows: highly active: MIC below $1 \mu \mathrm{g} / \mathrm{mL}$ (or $2.5 \mu \mathrm{M}$ ), significantly active: $1 \leq \mathrm{MIC}$ $\leq 10 \mu \mathrm{g} / \mathrm{mL}$ (or $2.5 \leq \mathrm{MIC}<25 \mu \mathrm{M}$ ), moderately active: $10<\mathrm{MIC} \leq 100 \mu \mathrm{g} / \mathrm{mL}$ (or $25<\mathrm{MIC} \leq 250 \mu \mathrm{M}$ ), low activity: $100<$ MIC $\leq 1000 \mu \mathrm{g} / \mathrm{mL}$ (or $250<$ MIC $\leq 2500 \mu \mathrm{M}$ and not active: MIC $>1000 \mu \mathrm{g} / \mathrm{mL}$ (or $>2500 \mu \mathrm{M})$ [40]. Based on this, most of the antimicrobial activities of the tested triterpenoid and phenolic derivatives could be considered as significant, moderate and weak depending on the sensitive microorganisms.
As mentioned previously, triterpenes are known to display significant antimicrobial properties [41-43]. With this in mind, we examined the inhibitory activity of compounds 3, 4, 9 and 13 against $S$. aureus and yeast strains. Although the isolated triterpenoid derivatives did not display any significant antimicrobial activity, these compounds showed some moderate and weak anti-staphylococcal activity as well as weak antifungal activity against $C$. albicans, $C$. tropicalis and C. neoformans. Generally, compounds 7, 10 and the mixture of $\mathbf{1 0}+\mathbf{1 2}$ showed prominent activity against methicillin-resistant $S$. aureus MRSA3 and MRSA4 and other microbes. Although the test compounds were not as active as the standard drugs, ciproflaxacin and nystatin, these compounds may be employed in situations where there is resistance to anti-staphylococcal drugs. Compounds $\mathbf{7}$ and $\mathbf{1 0}$ are therefore the lead candidates in the search for antimicrobial agents.

From the structure-activity-relationship point of view, compounds $\mathbf{4}, 5$ and 6 with the same basic skeleton, have the sugar moieties which should be responsible for the differences in their activity. The difference in the antimicrobial activity of compounds 7 and 10 suggests that the contribution of electron- 


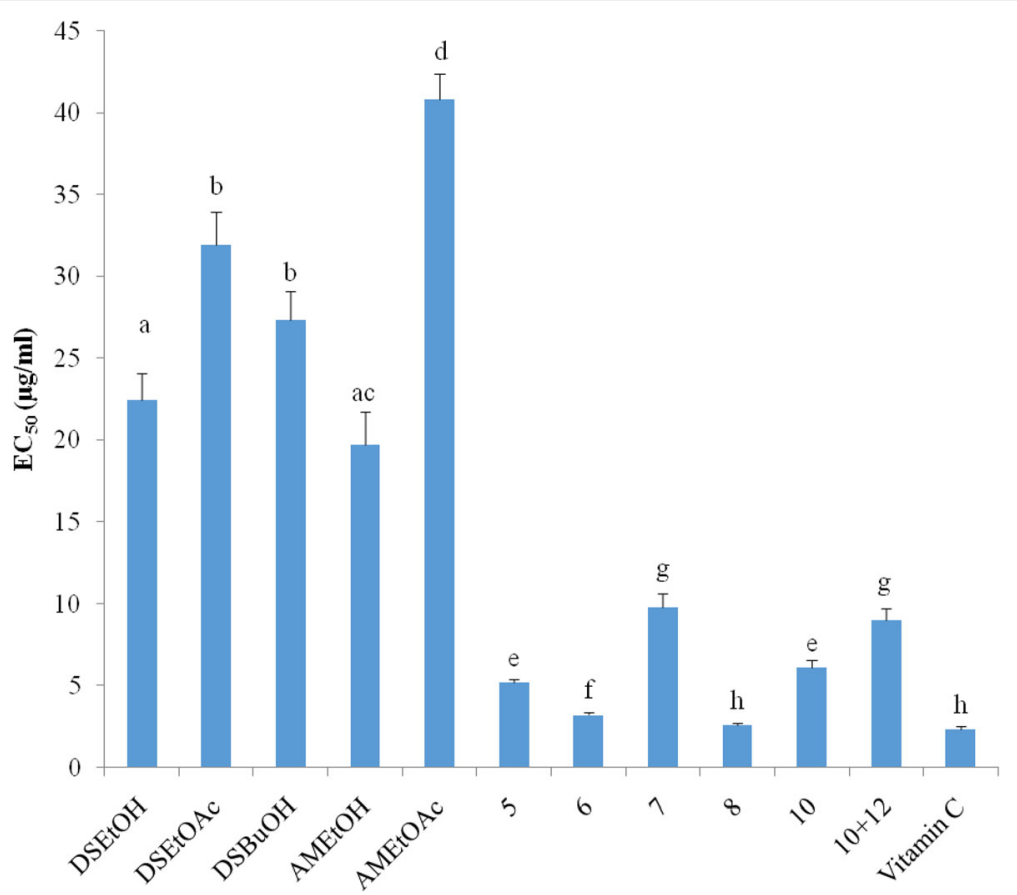

Fig. 3 Equivalent concentrations of tested samples scavenging $50 \%$ of DPPH radical $\left(E C_{50}\right.$ ). Results represent the mean \pm standard deviation of the triplicate $\mathrm{EC}_{50}$ of each sample. Letters a - $\mathrm{h}$ indicate significant differences between samples according to one way ANOVA and Waller Duncan test; $p<0.05$. Compounds $\mathbf{1 - 2}, \mathbf{1 1}$ and $\mathbf{1 4}$ were not tested; compounds $\mathbf{3 - 4 ,} \mathbf{9}$ and $\mathbf{1 3}$ were not active; DSEtOH=D. senegambiensis $\mathrm{EtOH}$ extract; $\mathrm{DSEtOAc}=D$. senegambiensis EtOAc extract; $\mathrm{DSBuOH}=D$. senegambiensis $n-\mathrm{BuOH}$ extract; $\mathrm{AMEtOH}=A$. monticola EtOH extract; $\mathrm{AMEtOAc}=$. monticola EtOAc extract

donating groups $\left(-\mathrm{OH}\right.$ and $\left.-\mathrm{OCH}_{3}\right)$ is remarkable in influencing the activity. The antimicrobial activities of purified phenolic derivatives corroborate with those of the early reports against bacteria and fungi $[5,26,44]$. The antimicrobial inhibitory mechanisms of phenolic compounds found active in this study, may be due to iron deprivation or hydrogen bounding with vital proteins such as microbial enzymes [45]. Lipophilic flavonoids may disrupt microbial membranes whereas terpenes may have the ability to disrupt microbial membrane and this may explain their antimicrobial properties [46].

Reducing power is associated with antioxidant activity and may serve as a significant reflection of the antioxidant activity [47]. In this study, the crude extracts, fractions and isolated compounds from $D$. senegambiensis and $A$. monticola exhibited concentration-dependent reducing power. The reducing capacity of extracts is much related to the presence of biologically active compounds (phenols) with potent donating abilities [48]. The antioxidant potential of each extract/compound was also measured using the change in its absorbance of decolourized DPPH free-radical as it accepts electrons from the antioxidant-rich samples. A free radical is a species capable of independent existence that contains one or more unpaired electrons. Free radicals contribute to the elimination of infected cells, but they can also react with cellular DNA or other macromolecules, either damaging them directly or setting in motion a chain reaction resulting in extensive damage of cellular structures [49]. The present study showed that the free radical scavenging activity of $D$. senegambiensis and A. monticola is due to the presence of antioxidant-rich compounds like phenolic derivatives. Indeed, phenolic compounds are known to be potential antioxidants due to their ability to scavenge free radicals and active oxygen species such as singlet oxygen, superoxide anion and hydroxyl radicals [50]. Hence, the presence of such compounds could explain the antioxidant activity found in the studied plant extracts. The results of the antioxidant study show that extracts from $D$. senegambiensis and $A$. monticola as well as compounds 5-8, 10 and mixture of $\mathbf{1 0}+\mathbf{1 2}$ may have great relevance in the prevention and therapies of diseases in which oxidants or free radicals are implicated.

\section{Conclusions}

The phytochemical study of the EtOH extracts from the studied plant species afforded fourteen triterpenoid and phenolic derivatives. Compounds obtained from D. senegambiensis are $\beta$-amyrin palmitate (1), $\alpha$-amyrin acetate (2), ursolic acid (3), sitosterol-3-O- $\beta$-D-glucopyranoside (4); vitexin (5) and trans-tiliroside (6). Ursolic acid (3), sitosterol3-O- $\beta$-D-glucopyranoside (4), 3,4'-di-O-methylellagic acid 
(7), dimethyl 4,4',5,5',6,6'-hexahydroxybiphenyl-2,2'-dicarboxylate (8), lupeol (9), ellagic acid (10), 3-hydroxy4,5-dimethoxybenzoic acid (11), 3-O-methylellagic acid 4'-O- $\beta$-D-xylopyranoside (12), oleanolic acid (13), and amphiblemmone A (14) were isolated from A. monticola. The present study revealed the potential of $D$. senegambiensis and $A$. monticola as well as the most active compounds $(7,8$ and 10) in the search for new antimicrobial and antioxidant agents. So, further investigations are needed.

\section{Additional files}

Additional file 1: NMR and Mass spectra of isolated compounds from

D. senegambiensis and A. monticola. (PDF $1113 \mathrm{~kb}$ )

\begin{abstract}
Abbreviations
${ }^{13}$ C-NMR: Carbon thirteen Nuclear Magnetic Resonance; ${ }^{1} H$ NMR: Proton Nuclear Magnetic Resonance; AMEtOAc: A. monticola EtOAc extract; AMEtOH: A. monticola EtOH extract; ATCC: American Type Culture Collection; CC: column chromatography; DMSO: Dimethylsulfoxide; DSBUOH: D. senegambiensis n-BuOH extract; DSEtOAc: D. senegambiensis EtOAc extract; DSEtOH: D. senegambiensis EtOH extract; EtOAc: Ethyl acetate; EtOH: Ethanol; HNC: Herbier National du Cameroun; IR: Infra-red; MBC: Minimum bactericidal concentration; MFC: Minimum fungicidal concentration; MHA: Mueller Hinton agar; MHB: Mueller Hinton broth; MIC: Minimum inhibitory concentration; MMC: Minimum Microbicidal Concentrations; MS: Mass Spectrometry; NA: Nutrient agar; n-BuOH: n-Butanol; NMR: Nuclear Magnetic Resonance; SDA: Sabouraud Dextrose Agar; SDB: Sabouraud Dextrose Broth; SRF/ CAM: Section de réserve forestière du Cameroun; TLC: Thin Layer Chromatography; UV: Ultra-violet
\end{abstract}

\section{Acknowledgements}

Authors are also thankful to the Institute of Medical Mycology, Teikyo University in Japan for providing some clinical bacteria and fungi.

\section{Funding}

The authors gratefully acknowledge financial support from the research grant committees of both the University of Dschang and the Cameroonian Ministry of Higher Education. They also thank TWAS-UNESCO for a 6 months research grant at ICCBS, University of Pakistan to one of them (Ndjateu, F.S.T.). We are also grateful to the Japan Society for the promotion of science for postdoctoral fellowship awarded to Dr. M. D. Awouafack as an overseas researcher to work at the Institute of Natural Medicine, University of Toyama.

\section{Availability of data and materials}

The datasets used and/or analyzed during the current study are available from the corresponding author on reasonable request. Plant materials used in this study have been identified at the Cameroon National Herbarium where voucher specimens are deposited.

\section{Authors' contributions}

RTN, FSTN and MDA carried out the chemical part; SEE and JAMF did the biological part; MT, PT, HM and MIC contributed to structural elucidation and supervised the chemical part; JDT designed the experiments, supervised the biological part and helped in manuscript writing and editing; all authors read and approved the final manuscript.

\section{Ethics approval and consent to participate}

Not applicable in this section.

\section{Competing interests}

The authors declare that they have no competing interests.

\section{Publisher's Note}

Springer Nature remains neutral with regard to jurisdictional claims in published maps and institutional affiliations.

\section{Author details}

'Laboratory of Natural Products Chemistry, Department of Chemistry, Faculty of Science, University of Dschang, P.O. Box 67, Dschang, Cameroon. ${ }^{2}$ Laboratory of Microbiology and Antimicrobial substances, Department of Biochemistry, Faculty of Science, University of Dschang, P.O. Box 67, Dschang, Cameroon. Institute of Natural Medicine, University of Toyama, 2630-Sugitani, Toyama 930-0194, Japan. ${ }^{4}$ H.E.J Research Institute of Chemistry, University of Karachi, -75270 , Karachi, Pakistan.

Received: 30 January 2018 Accepted: 4 May 2018

Published online: 16 May 2018

\section{References}

1. Iwu MM, Duncan AR, Okunji CO. New antimicrobials of plant origin. In: Janick J, editor. Perspectives on new crops and new uses. Alexandria: ASHS Press; 1999

2. Mahady GB, Huang Y, Doyle BJ, Locklear T. Natural products as antibacterial agents. Nat Prod Chem. 2008;35:423-44.

3. Tatsimo NSJ, Tamokou JD, Lamshöft M, Mouafo TF, Lannang MA, Sarkar P, et al. LC-MS guided isolation of antibacterial and cytotoxic constituents from Clausena anisata. Med Chem Res. 2015;24(4):1468-79.

4. Pagning NAL, Tamokou JD, Lateef M, Tapondjou AL, Kuiate JR, Ngnokam D, et al. New triterpene and new flavone glucoside from Rhynchospora corymbosa (Cyperaceae) with their antimicrobial, tyrosinase and butyrylcholinesterase inhibitory activities. Phytochem Lett. 2016;16(1):121-8.

5. Tebou PLF, Tamokou JD, Ngnokam D, Voutquenne-Nazabadioko L, Kuiate JR, Bag PK. Flavonoids from Maytenus buchananii as potential cholera chemotherapeutic agents. South Afri J Bot. 2017;109:58-65.

6. Loigier HA. Descriptive flora of Puerto Rico and adjacent islands, Spermatophyta: Cyrillaceae to Myrtaceae, vol 3. Puerto Rico: University of Puerto Rico Press; 1994, p 462.

7. Maluma V. Les antherotomadissotis (inl. heterotis), Melastomataceae endémiques d'Afrique Centrale. Revue de Taxonomie et de Nomenclature Botaniques; 2005. p. 1-18.

8. Tchebemou BB, Nganso DYO, Soh D, Zondegoumba NTE, Toghueo KRM, Sidjui SL, et al. Chemical constituents of Dissotis perkinsiae (Melastomaceae) and their antimicrobial activity. J Appl Pharm Sci. 2016;6:96-101.

9. Bellakhdar J. La pharmacopée Marocaine traditionnelle: Médecine arabe ancienne et savoirs populaires, vol. 1. Paris-Rabat: Ibis Press-Eds Le Fennec; 1997. p 764.

10. Cheek M, Woodgyer EM. New data on Amphiblemma monticola Jacq.-Fél. (Melastomataceae) from western Cameroon. Kew Bull. 2006;61:601-4.

11. Jacques-Félix H. Le genre Amphiblemma Naud.(Melastomatacées). Adansonia. 1973;2:429-59.

12. Jacques-Félix H. Un Amphiblemma (Melastomataceae) nouveau du Cameroun. Bulletin du Muséum National d'Histoire Naturelle, Section B. Adansonia. 1987;9:125-7.

13. Ndjateu FST, Tene M, Tane P, Choudhary MI. A new C-methyl isoflavone and other compounds from the roots of Amphiblemma monticola (Melastomataceae). Nat Prod Commun. 2017;12:1731-2.

14. Calderon Al, Terreaux C, Schenk K, Pattison P, Burdette JE, Pezzuto JM, et al. Isolation and structure elucidation of an isoflavone and a sesterterpenoic acid from Henriettella fascicularis. J Nat Prod. 2002;12:1749-53.

15. Zhang Z, Elsohly HN, Li XC, Khan SI, Broedel SE Jr, Raulli RE, et al. Flavanone glycosides from Miconia trailli. J Nat Prod. 2003;66:39-41.

16. Ndjateu FST, Tsafack RBN, Nganou BK, Awouafack MD, Wabo HK, Tene M, et al. Antimicrobial and antioxidant activities of extracts and ten compounds from three Cameroonian medicinal plants: Dissotis perkinsiae (Melastomataceae), Adenocarpus mannii (Fabaceae) and Barteria fistulosa (Passifloraceae). South Afri J Bot. 2014:91:37-42.

17. Nono RN, Barboni L, Teponno RB, Quassinti L, Bramucci M, Vitali LA, et al. Antimicrobial, antioxidant, anti-inflammatory activities and phytoconstituents of extracts from the roots of Dissotis thollonii Cogn. (Melastomataceae). South Afri J Bot. 2014;93:19-26.

18. Serna DM, Martinez JH. Phenolics and polyphenolics from Melastomataceae species. Molecules. 2015;20:17818-47.

19. Evans WC. Trease and Evans Pharmacognosy. 13th ed. Traiadal, London: Bailere; 1989.

20. Harborne JB. Phytochemical methods: a guide to modern techniques of plant analysis. 2nd ed. London: Chapman and Hall Publishers; 1998.

21. Tiwari P, Kumar B, Kaur M, Kaur G, Kaur H. Phytochemical screening and extraction: a review. Int Pharm Sci. 2011;1:98-106. 
22. Banu S, Cathrine L. General techniques involved in phytochemical analysis. Int J Adv Res Chem Sci. 2015;2:25-32.

23. Tsemeugne J, Sopbué FE, Tamokou JD, Tonle I, Kengne IC, Ngongang DA, et al. Electrochemical behavior and in vitro antimicrobial screening of some thienylazoaryls dyes. Chem Cent J. 2017;11:119.

24. Tamokou JD, Tala FM, Wabo KH, Kuiate JR, Tane P. Antimicrobial activities of methanol extract and compounds from stem bark of Vismia rubescens. J Ethnopharmacol. 2009;124:571-5.

25. Padmaja M, Sravanthi M, Hemalatha KPJ. Evaluation of antioxidant activity of two Indian medicinal plants. J phytol. 2011;3:86-91.

26. Djouossi MG, Tamokou JD, Ngnokam D, Kuiate JR, Tapondjou AL, Harakat D, et al. Antimicrobial and antioxidant flavonoids from the leaves of Oncoba spinosa Forssk. (Salicaceae). BMC Compl Altern Med. 2015;15:134.

27. Situ H, Bobek LA. In vitro assessment of antifungal therapeutic potential of salivary histatin-5, two variants of histatin-5, and salivary mucin (MUC7) domain 1. Antimicrob Agents Chemother. 2000:44:1485-93.

28. Marizeth LB, Jorge MD, Pedro Ade PP, Maria LSG, Juceni PD. Fatty acid esters of triterpenes from Erythroxylum passerinum. J Braz Chem Soc. 2002; 13:669-73.

29. Nkeoma NO, Daniel LA, Henry NO, Emmanuel El, Chukwuemeka SN, Festus BCO. Beta-Amyrin and alpha-amyrin acetate isolated from the stem bark of Alstonia boonei display profound anti-inflammatory activity. Pharm Biol. 2014;52:1478-86.

30. Seebacher $W$, Simic $N$, Weis $R$, Saf $R$, Kunert $O$. Complete assignments of ${ }^{1} \mathrm{H}$ and ${ }^{13} \mathrm{C}$ NMR resonances of oleanolic acid, 18a-oleanolic acid, ursolic acid and their 11- oxo derivatives. Magn Reson Chem. 2003:41:636-8.

31. Tene M, Tane P, Tamokou JD, Kuiate JR, Connolly JD. Degraded diterpenoids from the stem bark of Neoboutonia mannii. Phytochem Lett. 2008;1:120-4.

32. Ping W, Huiying $H$, Ruwei W, Naili W, Xinsheng Y. C glycosylfavones and aromatic glycosides from Campylotropis hirtella (Franch.) Schindl. Asian J Trad Med. 2007;2:149-53.

33. Timmers M, Urban S. On-line (HPLC-NMR) and off-line phytochemical profiling of the Australian plant Lasiopetalum macrophyllum. Nat Prod Commun. 2011;7:551-60.

34. Zhang F, Fu T-J, Peng S-L, Liu Z-R, Ding L-S. Two new triterpenoids from the roots of Sanquisorba officinalis L. J Integr Plant Biol. 2005;47:251-6.

35. Alam A, Takaguchi Y, Tsuboi S. Synthesis of ellagic acid and its 4,4'-di-O-alkyl derivatives from gallic acid. J Fac environ Sci Technol. Okayama University. 2005;10:111-7

36. Wang C-M, Chen H-T, Wu Z-Y, Jhan Y-L, Shyu C-L, Chou C-H. Antibacterial and synergistic activity of pentacyclic triterpenoids isolated from Alstonia scholaris. Molecules. 2016;21(2):139.

37. Brown BR, Brown PE, Pike WT. The leaf tannin of willow-herb [Chamaenerion angustifolium (L.) Scop.]. Biochem J. 1966;100:733-8.

38. Yang X-H, Guo Y-W. Two new ellagic acid glycosides from leaves of Diplopanax stachyanthus. J Asian Nat Prod Res. 2004;6:271-6.

39. Reuben KD, Abdulrahman Fl, Akan JC, Usman H, Sodipo OA, Egwu GO. Phytochemical screening and in vitro antimicrobial investigation of the methanolic extract of Croton Zambesicus Muell ARG. Stem bark. Eur J Sci Res. 2008;23(1):134-40

40. Tamokou JD, Mbaveng TA, Kuete V. Antimicrobial activities of African medicinal spices and vegetables. In: Medicinal spices and vegetables from Africa: therapeutic potential against metabolic, inflammatory, infectious and systemic diseases. 1st ed: Elsevier; 2017, Chapter 8. p. 207-37.

41. Tene M, Ndontsa LB, Tane P, Tamokou JD, Kuiate JR. Antimicrobial diterpenoids and triterpenoids from the stem bark of Croton macrostachys. Int J Biol Chem Sci. 2009;3:538-44.

42. Chouna JR, Tamokou JD, Nkeng-Efouet-Alango P, Lenta NB, Sewald N. Antimicrobial triterpenes from the stem bark of Crossopteryx febrifuga. Zeitschrift für Naturforschung C. 2015;70(7-8):c:169-73.

43. Catteau L, Zhu L, Van Bambeke F, Quetin-Leclercq J. Natural and hemisynthetic pentacyclic triterpenes as antimicrobials and resistance modifying agents against Staphylococcus aureus: a review. Phytochem Rev 2018. https://doi.org/10.1007/s11101-018-9564-2.

44. Tatsimo NSJ, Tamokou JD, Havyarimana L, Dezso C, Forgo P, Hohmann J, et al. Antimicrobial and antioxidant activity of kaempferol rhamnoside derivatives from Bryophyllum pinnatum. BMC Res Notes. 2012;5:158.

45. Scalbert A. Antimicrobial properties of tannins. Phytochemistry. 1991;30:3875-83.
46. Cowan MM. Plant products as antimicrobial agents. Clin Microbiol Rev. 1999:12:564-82

47. Olayinka AA, Anthony IO. Preliminary phytochemical screening and in vitro antioxidant activities of the aqueous extract of Helichrysum longifolium DC BMC Complement Altern Med. 2010;10:21.

48. Li Y, Guo C, Yang J, Wei J, Xu J, Cheng S. Evaluation of antioxidant properties of pomegranate peel extract in comparison with pomegranate pulp extract. Food Chem. 2006;96(2):254-60.

49. Karou D, Nadembega WMC, Ouattara L, Ilboudo DP, Canini A, Nikiéma JB, et al. African ethnopharmacology and new drug discovery. Med Aromat Plant Sci Biotechnol. 2007;1(1):1-9.

50. Pietta P, Sionetti P, Mauri P. Antioxidant activity of selected medicinal plants J Agric Food Chem. 1998;46:4487-90

\section{Ready to submit your research? Choose BMC and benefit from:}

- fast, convenient online submission

- thorough peer review by experienced researchers in your field

- rapid publication on acceptance

- support for research data, including large and complex data types

- gold Open Access which fosters wider collaboration and increased citations

- maximum visibility for your research: over $100 \mathrm{M}$ website views per year

At BMC, research is always in progress.

Learn more biomedcentral.com/submissions 